\title{
THE SELECTION OF PPP TYPE THROUGH VALUE FOR MONEY ANALYSIS: A CASE STUDY OF JAKARTA-SURABAYA RAILWAY PROJECT
}

\author{
Dwi Agus Purnomo ${ }^{1 *}$, Yulianta ${ }^{1}$, Djoko Prijo Utomo ${ }^{1}$, Sucipto $^{1}$ \\ ${ }^{1}$ Center for Technology for Transportation System and Infrastructure, Agency for the Assessment \\ and Application of Technology, South Tangerang 15314, Indonesia
}

(Received: February 2020 / Revised: April 2020/ Accepted: May 2020)

\begin{abstract}
With the suboptimal performance of the Jakarta-Surabaya corridor railway currently operating, the Government of Indonesia intends to upgrade the railway system in terms of speed performance as well as to engage the participation of both the public and private sectors in the upgrading project as mandated in Presidential Regulation Number 38/2015. Through this research, the type selection of the Public-Private Partnership (PPP) scheme and their implications on the Jakarta-Surabaya railway project will be demonstrated by conducting analysis to the alternative scenarios of the study on railway technology selection with an emphasis on economic and financial feasibility aspects to determine the suitable PPP type, which is validated through Value for Money (VfM) analysis, where the benefits of the selected PPP type in terms of economic, financial, and non-financial aspects were examined through numerical tests, the result of which indicated that with the VfM value of the actual data of IDR 224.51 trillion, and the most significant changes in VfM value for each variable change are in the 20 -year concession period which reduces the VfM value by $4 \%$. Of all the variable changes, there is no minus VfM value, indicating that public projects are in an improved condition with the PPP scheme.
\end{abstract}

Keywords: PPP; Railway; Regulation; Value for Money

\section{INTRODUCTION}

The railway track on the northern coast of Java Island that currently uses a narrow-gauge spoor system of $1,067 \mathrm{~mm}$ is stretched between Jakarta and Surabaya at about $718 \mathrm{~km}$ distance (Utomo et al., 2020). Around ten locations along the track were identified to have a curved radius of less than $500 \mathrm{~m}$, which would impede the speed of train operations. Moreover, the amount of level crossings, that reaches around 1,000 locations has also become a critical issue for the service performance of this railway system since there is a collision risk between trains and road vehicles or pedestrians (Evans, 2013). This railway route has several class trains ranging from economy, business, and executive using diesel locomotives, with the fastest travel time from Jakarta to Surabaya of about 9.5 hours. Jakarta and Surabaya, two biggest cities in Indonesia, with a population of 10.55 million (BPS-Statistics of DKI Jakarta Province, 2020) and 3.15 million in 2019 (BPS-Statistics of Surabaya Municipality, 2020), respectively, are the magnets to their surrounding cities.

\footnotetext{
*Corresponding author's email: dwi.agus@bppt.go.id, Tel. +62-21-75875944 ext 140, Fax. +62-21-75875946 DOI: https://doi.org/10.32783/csid-jid.v3i1.117
} 
The population of Jakarta and its satellite cities (Jabodetabek) of about 27.9 million, Semarang and its neighboring cities (Kedungsepur) of 5.8 million, and Surabaya metropolitan area (Gerbangkertosusila) of 9.1 million, combined together can reach $31.25 \%$ of total the Java's population. While the economic potential of these regions reaches $47.24 \%$ of the total national GDP.

However, based on the results of the initial feasibility study conducted by the Agency for the Assessment and Application of Technology (BPPT), an alternative mass transportation mode is required (Directorate of System and Infrastructure Transportation, 2017). Thus, considering its close relationship with the national economic development (Chen et al., 2016), the Jakarta Surabaya train service as a mode of transportation that is economical, safe, and with a relatively large number of passengers carrying capacity needs to be upgraded (Nurhidayat et al., 2018).

Based on the issues that have been described above, it is apparent that a more detailed technical study is needed to reach the implementation stage in the form of a pre-feasibility study on the upgrading of Jakarta - Surabaya rail system. From the results of the pre-feasibility study, particularly regarding the aspects of economic and financial studies, several selections of Public-Private Partnership (PPP) types can then be summarized based on the applicable rules that are in accordance with the guidelines outlined by Ministry of National Development Planning/ National Development Planning Agency.

\section{LITERATURE STUDY}

\subsection{Determination of PPP Scheme in Indonesia}

In order to determine the type of PPP scheme for this project, it is necessary to study related literature and review the relevant data. Some of the primary literature that underlies the type determination of PPP scheme include: (1) Pre-feasibility Study on the Speed Improvement of Jakarta-Surabaya Railway (Directorate of System and Infrastructure Transportation, 2017); (2) Presidential Regulation 38/2015 on Cooperation between Government and Business Entity in Infrastructure Provision; and (3) Web-based PPP Toolkit Preparation (Bappenas, 2016).

The Pre-Feasibility Study on the Speed Improvement of Jakarta-Surabaya Railway was intended for analyzing the selection of the revitalization model or the construction of the best railway infrastructure and facilities to be implemented in the Jakarta-Surabaya railway corridor using the Public-Private Partnership scheme. The pre-feasibility study activities included:

1. Comparative analysis of various choices of high-speed railway technology $\left(V_{\max }>200\right.$ $\mathrm{km} / \mathrm{h})$ and normal speed railway technology $\left(V_{\max }<200 \mathrm{~km} / \mathrm{h}\right)$;

2. Assessment of project feasibility for the selected railway technology. This project is expected to attract private sectors in investing around $51 \%$ of the project value; therefore, government support through the national budget (APBN) can be optimized to less than $49 \%$ of the project value. Returns on investment of the private sector may be obtained from levies on the use of railway infrastructure or Track Access Charges (TAC) from railway facility business entities and/or other revenues;

3. Basic design of the selected railway corridors according to the results of the project feasibility assessment and preparation of business entity tender documents (investors) is carried out using design and build method, hence project implementation is expected to be more efficient in terms of time and cost;

4. Preparation of a realistic project implementation action plan

PPP toolkit preparation book was published by Bappenas in order to facilitate the 
government to proceed with the implementation of the proposed PPP project starting from the initial stage until the final stage, which includes the PPP planning phase, PPP preparation phase, PPP transaction, and further implementation of PPP (see Figure 1).

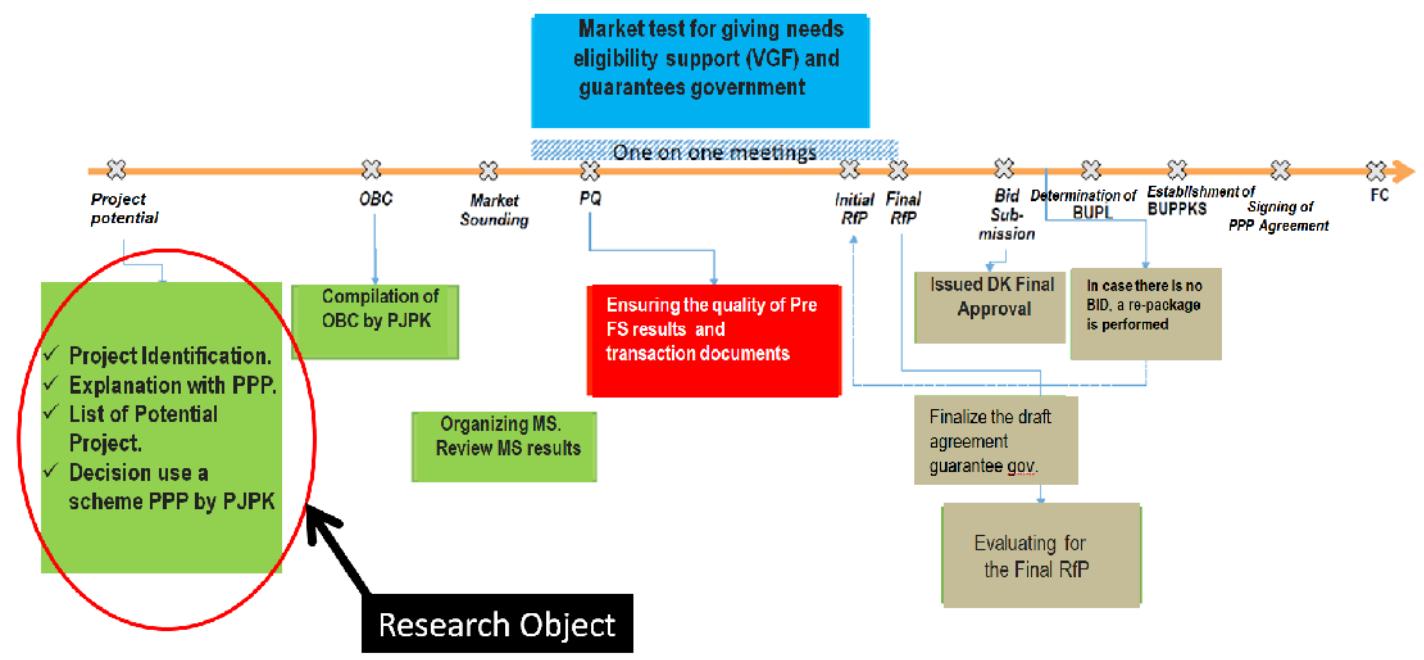

Figure 1 PPP Implementation Flow

This research only covers the potential stage of the project from the PPP planning aspects. After the PPP type that will be implemented in the project is determined, then it will be validated through the Value for Money (VfM) method, in order to measure the extent of the project benefits to the government in terms of economic, financial, and technical aspects.

\subsection{Value for Money (VfM)}

Value for Money (VfM) is the optimum combination of all costs in the life cycle, risk, fulfillment of time and quality of the project that aims to meet public demand, also as a consideration in deciding to carry out the project by the PPP method or not (Grimsey \& Lewis, 2002; Morallos et al., 2009; Nisar, 2007). VfM analysis broadly covers the value for money of the total overall costs in the asset life cycle, which consists of investment, construction, and operation and maintenance. The data included in the analysis consist of data on the financial feasibility of assets, material intensity, and energy, which is required to meet the objectives and resilience of public demand and obtain a positive social multiplier effect.

Quantitative measurement of infrastructure project optimization is by utilizing Public Sector Comparator (PSC) (Ismail et al., 2012), a cost that is made as a comparison by estimating the value of service quality, price, timeframe, risk allocation, and certainty, to provide benefits equivalent to the PPP scheme (Hui et al., 2010). It is done by comparing similar projects in the same sector in their form of the traditional procurement system, such as the government's support efforts and the level of competition created. In the calculation flow of VfM, there is a cost comparison that is done by estimating the value of service, quality, price, timeframe, risk allocation, and certainty in providing benefits equivalent to the PPP scheme (Morallos \& Amekudzi, 2008).

The scheme and characteristics of PPP models vary greatly; hence they must be determined at the planning stage ( $\mathrm{Ng}$ et al., 2012). Variations in PPP models occur due to the rapid development of a "new style" type of financing for mega-scale projects called project financing, an activity involving companies as sponsors in investing and having the sole purpose of 
industrial assets (generally with a limited life span) through independent legal entities and financed with non-recourse debt, which ultimately has direct consequences for the development of the legal sector in the field concerned, including the development of forms of cooperation patterns (Zhang, 2005). For this reason, an alternative PPP model needs to be examined before determining the PPP scheme. The modalities in the VfM analysis include the level of efficiency from the PPP types (Vives et al., 2010), which are elaborated from the types of Pure PPPs, Viability Gap of Finance (VGF) PPPs, Available of Payment (AP) PPPs, Operational \& Maintenance (OM) PPPs (National Budget + OM) to State-Owned Enterprises (SOE).

The quantification in the VFM analysis includes Basic PSC, Retained Risk, Competitive Neutrally, and transferable risk data, with the following details (Bappenas, 2016):

1. Basic PSCs include data: discount rates, availability of historical project data on traditional procurement, historical data of traditional procurement projects, OM project costs on traditional procurement, Government support, investment scale, and project scope, Government and business entity involvement, and competition level.

2. Retained Risk includes data: Government risk measurement, Government risk mitigation, evaluation of the occurrence of Government risk, the ability of the public sector to manage risk.

3. Competitive Neutrally includes data: project level, business management costs.

4. Transferable risk includes data: Business Entity's appetite in accepting risk, Business Entity's capacity in managing risk, Business Entity's perception in managing risk, Business Entity incentive system, Business Entity performance measurement.

The procedures of VfM observation begins with the formulation of the problem, continues with setting goals, leads to the study of literature and field studies, and then develops the model (Park et al., 2018). It is then followed by succession with verification, validation, data collection, numerical trials, and conclusions from the results of the study.

In order to get the VfM value which will be used in making decisions regarding the partnership in the project financing, the formulation used is as follows:

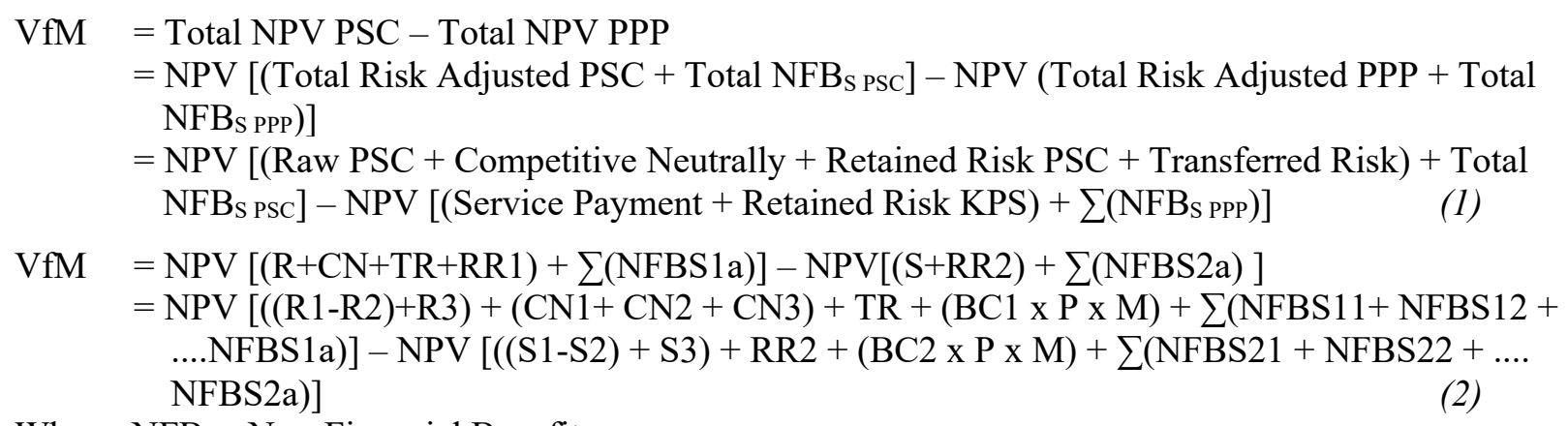

Where, $\mathrm{NFBs}=$ Non-Financial Benefits

If the VfM value obtained is positive, it means that the NPV of the PSC risk adjustment is greater than the NPV risk adjustment of the PPP. This indicates that public projects are recommended to be implemented under the PPP scheme with the involvement of private sector is required in their procurement.

The model verification is then carried out to ensure the truth of a model from the mathematical aspects and consistency of logic that is the basis of the development of the model, including observations on:

1. The results of selecting the crucial VfM criteria in the project will be used later as the output of risk reduction. 
2. Mean impact on the calculation of risk, used in the calculation of retained risk in PSC or PPP, with the formula: Base Cost $x$ risk probabilities $x$ mean impact

3. NFBs is calculated by using a quantitative approach to the currency unit.

After verification is done, model validation is carried out to check whether the model meets in the initial objectives of developing the model, including observation on:

1. Research validation including sensitivity analysis, numerical trials on the project development feasibility analysis data;

2. Reasons for using sensitivity analysis is to determine whether changes in the value of variables in the model will prove the sensitivity of the relationship between variables and parameters in the field.

3. Changes in variables made are changes in the concession period, changes in the proportion of investment, changes in Discount Factor.

\section{METHODOLOGY}

This paper investigates the type determination of the PPP scheme for the railway facility and infrastructure technology by evaluating the results of economic and financial studies of the case study project. The research activities to achieve the research objective can be seen in Figure 2.

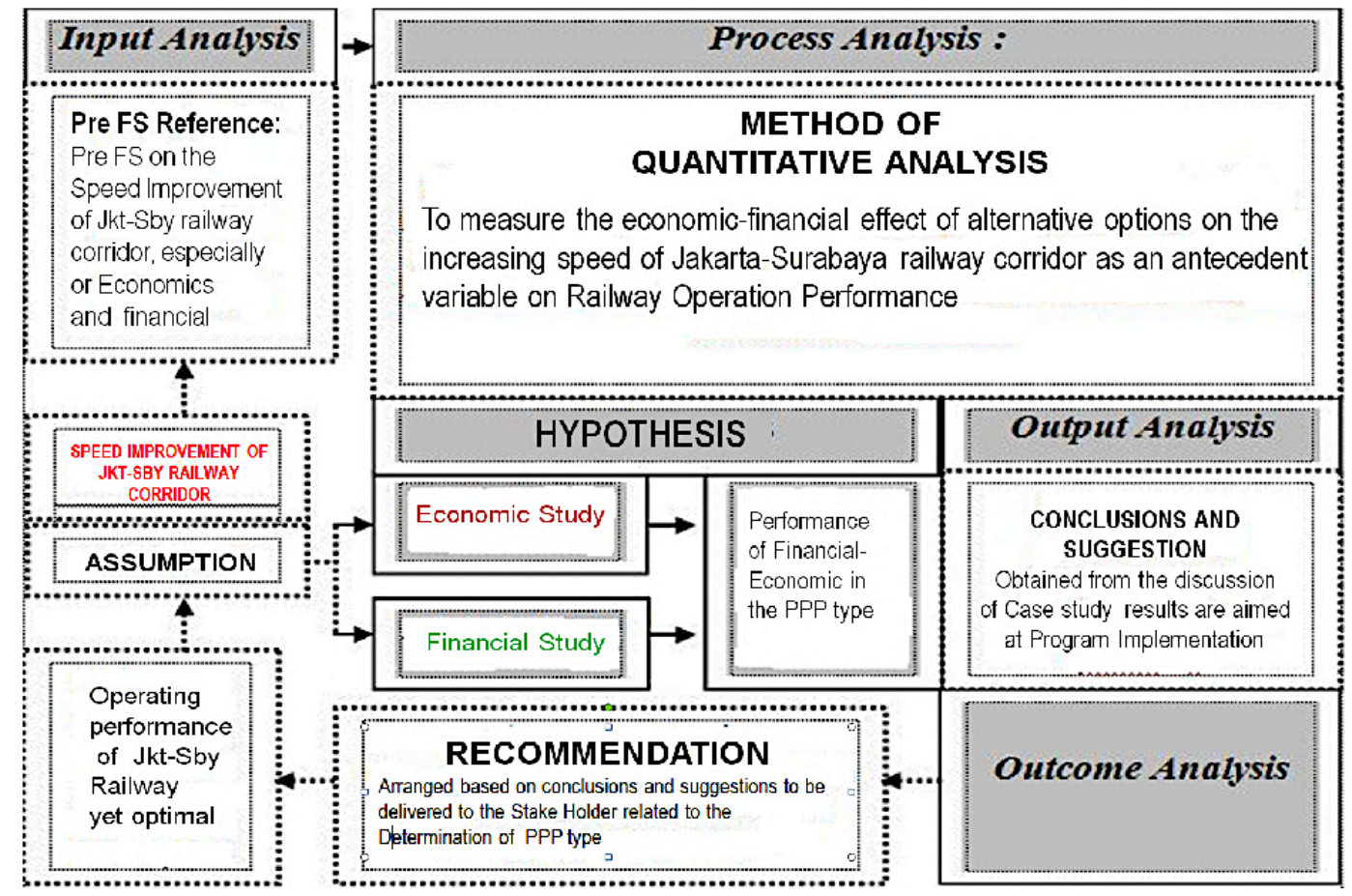

Figure 2 Research Activities

The procedures of the research activities conducted are as follow:

1. Input analysis is derived from the Pre-feasibility Study on the Speed Improvement of Jakarta-Surabaya Railway and railway operation performance data, particularly those concerning economic and financial aspects.

2. Quantitative analysis is done to measure the economic-financial effect of the impact of alternative choices on the Program of Speed Improvement of Jakarta-Surabaya Railway as an antecedent variable on the Jakarta-Surabaya railway operation performance.

3. Determine the hypotheses on the results of economic and financial studies and their direction on railway operation performance on the type of PPP selected. 
4. Output analysis, in the form of conclusions and facilities, is obtained from the discussion of the results of the economic and financial case study and the determination of the type of PPP according to the government's policy.

5. Outcome analysis is in the form of a recommendation for the type of PPP from an alternative choice for the Program on the Speed Improvement of Jakarta-Surabaya Railway.

6. Validation of determining the PPP type to determine the extent of economic and financial benefits for the Government on the proposed type of PPP chosen.

After the suitable PPP scheme has been selected, it will be validated through the Value for Money (VfM) analysis. This is done to decide whether the PPP project is feasible or not.

\section{RESULTS AND DISCUSSION}

\subsection{Presidential Regulation Number $38 / 2015$}

According to Presidential Decree 38 of 2015 and the procedure for PPP project implementation, the technical guideline of which were issued by Bappenas, the preparation of potential PPP projects from the initial stage to the final stage, which was illustrated in Figure 1 above, will take more than three years. Therefore, it is a challenge for the PPP project initiators to optimize time so that the whole implementation of the PPP project can be achieved in a period of fewer than three years. This absolutely requires innovation in technology related to the technical aspect as well as the economic-financial aspects of PPP.

\subsection{The Economic and Financial Studies of Pre-feasibility Study}

Based on the results of the economic and financial aspects studied in the Program of Speed Improvement of Jakarta-Surabaya Railway, there are four possible alternative scenarios that can be implemented, namely:

1. Alternative Scenario A in the form of the revitalization of the existing $718 \mathrm{~km}$ JakartaSurabaya Railway with the operating system comprises double track, narrow gauge, line sterilization, planned speed $\left(V_{\max }\right) 160 \mathrm{~km} / \mathrm{h}$, using existing telecommunications and signaling systems, DMU trains type.

2. Alternative Scenario $B$ is the addition of a new line in addition to the $718 \mathrm{~km}$ existing Jakarta-Surabaya Railway with the operating system comprises a single track, narrow gauge, rail line sterilization, planned speed $\left(V_{\max }\right) 160 \mathrm{~km} / \mathrm{h}$, using existing telecommunications and signaling, elevated track in urban areas and at grade in rural, DMU / EMU trains type.

3. Alternative Scenario $\mathrm{C}$ is the construction of a new line in addition to the $718 \mathrm{~km}$ existing Jakarta-Surabaya line with the operating system comprises a single track, standard gauge, without lane sterilization, planned speed $\left(V_{\max }\right)$ of $350 \mathrm{~km} / \mathrm{h}$, using telecommunications and standard of HST signaling, elevated track entirely, EMU trains type.

4. Alternative Scenario D is the construction of a new rail line outside the $718 \mathrm{~km}$ existing Jakarta-Surabaya line with the operating system comprises a double track, standard gauge, without lane sterilization, planned speed $\left(V_{\max }\right)$ of $350 \mathrm{~km} / \mathrm{h}$, using telecommunications and standard of HST signaling, elevated track entirely, EMU trains type.

The results of input analysis of the economic and financial aspects of the four alternative scenarios can subsequently obtain economic feasibility data (EIRR) and financial feasibility (FIRR) as well as the appropriate types of PPP, as can be seen in Table 1 and Table 2. 
Table 1 Comparison of Financial Feasibility for Scenario A and Scenario B

\begin{tabular}{|c|c|c|c|c|c|c|c|c|c|}
\hline \multirow{3}{*}{$\begin{array}{l}\text { No. } \\
\text { । }\end{array}$} & \multirow{2}{*}{ DESCRIPTION } & \multicolumn{8}{|c|}{ SCENARIO } \\
\hline & & \multicolumn{4}{|c|}{ SCENARIO A (EXISTING REVITALIZATION) } & \multicolumn{4}{|c|}{ SCENARIO B (Add Track ST NG JKT-SBY V160) } \\
\hline & ECONOMIC PARAMETER / PPP TYPE & $\begin{array}{c}\text { AP } \\
\text { (WACC10\%) }\end{array}$ & $\begin{array}{l}\text { VGF } 49 \%+ \\
\text { TOD14\% }\end{array}$ & $\begin{array}{c}\text { VGF } 49 \%+\text { TOD } \\
14 \%+G S 20 \%\end{array}$ & $\begin{array}{l}\text { OM Facility } \\
\text { +TOD14\% }\end{array}$ & $\begin{array}{l}\text { KPBU AP } \\
\text { (WACC10\%) }\end{array}$ & $\begin{array}{c}\text { AP } \\
\text { (WACC10\%) }\end{array}$ & $\begin{array}{l}\text { VGF } 49 \%+ \\
\text { TOD } 13 \%\end{array}$ & $\begin{array}{l}\text { OM Facility+ } \\
\text { TOD13\% }\end{array}$ \\
\hline & \begin{tabular}{l|l} 
a & Total Project (IDR Trillion)
\end{tabular} & 85,52 & 85,52 & 85,52 & 85,52 & & 120,98 & 120,98 & 120,98 \\
\hline & b Total Project without Fly Over, etc. & 53,20 & 53,20 & 53,20 & 53,20 & & 85,43 & 85,43 & 85,43 \\
\hline & c Investment (IDR Trillion) & 53,20 & 53,20 & 17,03 & 2,71 & & 85,43 & 27,03 & 2,71 \\
\hline & d Initial Tarrif (Rp.) & 550.000 & 550.000 & 550.000 & 550.000 & & 550.000 & 550.000 & 550.000 \\
\hline & e $\quad$ Increasing of tarrif per annum & $3,80 \%$ & $3,80 \%$ & $3,80 \%$ & $3,80 \%$ & & $3,80 \%$ & $3,80 \%$ & $3,80 \%$ \\
\hline & f Social Discount Factor (SDF) & $10 \%$ & $10 \%$ & $10 \%$ & $10 \%$ & $10 \%$ & $10 \%$ & $10 \%$ & $10 \%$ \\
\hline & $\mathrm{g}$ EIRR & $13 \%$ & $13 \%$ & $13 \%$ & $13 \%$ & $13 \%$ & $13 \%$ & $13 \%$ & $13 \%$ \\
\hline \multirow[t]{8}{*}{ II } & FINANCIAL ANALYSIS & & & & & & & & \\
\hline & a AP at NPV condition (IDR Trillion) & 88,58 & & & & & 188,34 & & \\
\hline & b Grace periode & 3,0 & 3,0 & 3,0 & 3,0 & & 3,0 & 3,0 & 3,00 \\
\hline & \begin{tabular}{l|l} 
c & FIRR
\end{tabular} & $11,29 \%$ & $2,75 \%$ & $4,93 \%$ & $37,69 \%$ & & $10,40 \%$ & $5,74 \%$ & $37,13 \%$ \\
\hline & d NPV Project (IDR Trillion) & 55,61 & $-26,39$ & $-11,42$ & 0,38 & & $3,54 \%$ & $(14,35)$ & 21,71 \\
\hline & e Pay Back Period & 20 & 20 & 20 & 10 & & 20 & 20,00 & 10,00 \\
\hline & \begin{tabular}{l|l}
$f$ & BEP Investment(in year)
\end{tabular} & 22,77 & 36,26 & 26,27 & 1,74 & & 17,82 & 27,46 & 8,97 \\
\hline & g BEP Total Project incl. Fly Over (ir & 34,98 & 42,81 & 38,56 & 32,53 & & 19,15 & 39,95 & 32,64 \\
\hline & & & & & & & & & \\
\hline \multicolumn{2}{|r|}{ FEASIBILITY } & $\begin{array}{c}\text { Not Feasible (Not } \\
\text { Enough Budget } \\
\text { from GOI) }\end{array}$ & Not Feasible & Not Feasible & $\begin{array}{l}\text { Feasible with } \\
\text { high } \% \text { TOD, it } \\
\text { must be any } \\
\text { fragmented } \\
\text { project only for }\end{array}$ & & $\begin{array}{c}\text { Not Feasible } \\
\text { (Not Enough } \\
\text { Budget from } \\
\quad \text { GOl) }\end{array}$ & Not Feasible & $\begin{array}{l}\text { Feasible with high } \\
\% \mathrm{TOD} \text {, it must be } \\
\text { any fragmented } \\
\text { project only for Jkt- } \\
\text { Smg }\end{array}$ \\
\hline & & & & & & & & & \\
\hline \multicolumn{2}{|r|}{ PPP SCHEME PROPOSED } & Non PPP & Non PPP & Non PPP & $\begin{array}{l}\text { OM Facility + } \\
\text { TOD } 14 \%\end{array}$ & & Non PPP & Non PPP & $\begin{array}{l}\text { OM Facility+ } \\
\text { TOD13\% }\end{array}$ \\
\hline
\end{tabular}

Table 2 Comparison of Financial Feasibility for Scenario C and Scenario D

\begin{tabular}{|c|c|c|c|c|c|c|c|}
\hline \multirow{3}{*}{$\begin{array}{l}\text { No. } \\
\\
\end{array}$} & \multirow{3}{*}{\begin{tabular}{|c|} 
DESCRIPTION \\
ECONOMIC PARAMETER / PPP TYPE
\end{tabular}} & \multicolumn{6}{|c|}{ SCENARIO } \\
\hline & & \multicolumn{3}{|c|}{ SCENARIO C (Add Track ST SG Jkt-Sby V250) } & \multicolumn{3}{|c|}{ SCENARIO D (NR DT SG Jkt-Sby V 250) } \\
\hline & & \multirow{2}{*}{\begin{tabular}{|r|c}
$\begin{array}{c}\text { AP } \\
\text { (WACC10\%) }\end{array}$ \\
115,57
\end{tabular}} & \multirow{2}{*}{$\begin{array}{c}\begin{array}{c}\text { VGF49 } \%+ \\
\text { GS20 } \%\end{array} \\
\text { +TOD5 } \% \\
115,57\end{array}$} & \multirow{2}{*}{$\begin{array}{l}\begin{array}{c}\text { OM Faciity+ } \\
\text { TOD } 5 \%\end{array} \\
115,57\end{array}$} & \multirow{2}{*}{\begin{tabular}{|c|}
$\begin{array}{c}\text { AP } \\
\text { (WACC10\%) }\end{array}$ \\
174,68 \\
\end{tabular}} & \multirow{2}{*}{$\begin{array}{c}\text { VGF49\%+ } \\
\text { TOD3\% } \\
174,68 \\
\end{array}$} & \multirow{2}{*}{$\begin{array}{c}\text { VGF49 } \%+ \\
\text { GS20 } \%+\text { TOD } \\
3 \% \\
174,68\end{array}$} \\
\hline & \begin{tabular}{l|l} 
a & Total Project (IDR Trillion)
\end{tabular} & & & & & & \\
\hline & b Total Project without Fly Over, etc. (II & 96,46 & 96,46 & 96,46 & 155,58 & 155,58 & 155,58 \\
\hline & c Investment (IDR Trillion) & 96,46 & 31,20 & 5,78 & 155,58 & 79,34 & 50,12 \\
\hline & d Initial Tarrif (Rp.) & 650.000 & 650.000 & 650.000 & 700.000 & 700.000 & 700.000 \\
\hline & e Increasing of tarrif per annum & $3,80 \%$ & $3,80 \%$ & $3,80 \%$ & $3,80 \%$ & $3,80 \%$ & $3,80 \%$ \\
\hline & f Social Discount Factor (SDF) & $10 \%$ & $10 \%$ & $10 \%$ & $10 \%$ & $10 \%$ & $10 \%$ \\
\hline & g EIRR & $13 \%$ & $13 \%$ & $13 \%$ & $13 \%$ & $13 \%$ & $13 \%$ \\
\hline \multirow[t]{8}{*}{ II } & FINANCIAL ANALYSIS & & & & & & \\
\hline & \begin{tabular}{l|l} 
a & AP at NPV condition (IDR Trillion)
\end{tabular} & 185,69 & & & 313,00 & & \\
\hline & b Grace periode & 4,00 & 4,00 & 4,00 & 5,00 & 5,00 & 5,00 \\
\hline & c FIRR & $10,70 \%$ & $10,78 \%$ & $29,68 \%$ & $10,80 \%$ & $10,29 \%$ & $12,09 \%$ \\
\hline & \begin{tabular}{l|l}
$d$ & NPV Project (IDR Trillion)
\end{tabular} & 87,91 & 27,16 & 58,95 & 140,57 & 72,71 & 69,56 \\
\hline & e Pay Back Period & 20,00 & 0,08 & 10,00 & 20,00 & 20,00 & 20,00 \\
\hline & f $\quad$ BEP Investment(in year) & 17,50 & 20,00 & 5,83 & 17,34 & 20,78 & 15,35 \\
\hline & g $\quad$ BEP Total Project incl. Fly Over (in ! & 18,68 & 26,82 & 25,43 & 19,81 & 24,84 & 24,29 \\
\hline \multicolumn{2}{|r|}{ FEASIBILITY } & $\begin{array}{l}\text { Not Feasible } \\
\text { (Not Enough } \\
\text { Budget from } \\
\quad \text { GOI) }\end{array}$ & Feasible & $\begin{array}{c}\text { Feasible but not } \\
\text { attractive for GOI }\end{array}$ & $\begin{array}{c}\text { Not Feasible } \\
\text { (Not Enough } \\
\text { Budget from } \\
\quad \text { GOI) }\end{array}$ & Marginal & Feasible \\
\hline \multicolumn{2}{|r|}{ PPP SCHEME PROPOSED } & Non PPP & $\begin{array}{l}\text { VGF49\%+ } \\
\text { GS20\%+ } \\
\text { TOD5\% }\end{array}$ & OM Facility & Non PPP & $\begin{array}{l}\text { VGF49\%+ } \\
\text { TOD3\% }\end{array}$ & $\begin{array}{l}\text { VGF49\%+ } \\
\text { GS20\%+ } \\
\text { TOD3\% }\end{array}$ \\
\hline
\end{tabular}

Note: $\mathrm{AP}=$ Available of Payment; VGF=Viability Gap Finance; GS=Government Supporting; $\mathrm{OM}=$ Operation and Maintenance; TOD $=$ Transit-Oriented Development; EIRR value for all scenarios as around $13 \%$. Percent value of TOD means the percentage of Farebox. 


\subsection{Quantitative Analysis}

Economic and financial are two aspects that are quite important in a PPP project, along with managerial and administrative aspects, organizational aspects, commercial aspects, and social aspects, because it can contribute significantly to the national economy. In this economic analysis, the total results or the productivity or benefits gained by the community as a whole from the project, referred to as 'the social returns' or 'the economic returns' is investigated.

On the other hand, the financial analysis mainly investigates the comparison between expenditure and project income, examines whether the project will be able to guarantee the funds needed, whether the project will have the ability to repay the funds and whether the project will be financially independent later. Financial analysis has an important meaning, particularly as an incentive to stimulate participants of the project implementation. Because however beneficial a project is for the economy as a whole, it will not be useful if they as the operators who carry out the project do not improve their conditions. In this study, the result of equity capital invested in projects known as 'private returns' is investigated.

a. General Data and Primary Data

General data include fiscal and monetary related economic policies, economy and population, traffic, travel production, accident rates and damage to similar modes of transportation and competitors, operational costs of similar modes of transport and competitors, list of tariffs for similar modes of transportation and competitors, total passenger, models and patterns of existing railway transportation operations of the same type, prices of goods and services for planning, construction and operating costs and other costs in the related project. Also, the linkage is previous studies related to the financialeconomic feasibility of railways and other similar studies. The reference is associated with the feasibility of economic, financial, regional development, and other related aspects.

Primary data in the form of survey results consist of three types of completing surveys, namely stakeholder interview surveys, origin-destination surveys, and user preferences, which are equipped with operational data surveys of similar modes of transport and competitors.

b. Data on economic aspects

The economic aspect is one of the crucial aspects of justifying, whether a project plan is feasible or not to proceed. The activities that need to be taken are identifying the data that is going to be used as material for economic feasibility analysis, which includes cost and benefit aspects.

c. Data on financial aspects

The financial aspect is also an important consideration to decide whether a project plan is feasible or not. Cost and income are two aspects that need to be considered in conducting an analysis of financial feasibility.

d. Quantitative analysis

Literature review, secondary data, and information collected in the data collection phase are then followed by a preliminary review and analysis process, in order to be able to describe the existing conditions and future policy plans, while the data obtained from the results of the field survey are followed by data processing, which includes data input, data compilation and data presentation in the form of tables and graphs.

The analysis phase is the main activity of this work, which includes the projections and estimates of the needs of the express train transportation, analysis of the needs of the main and supporting infrastructure, economic and financial feasibility analysis, and recommendations. The projection of investment cost needs is obtained from the input calculation of the projected travel transportation projections needs, among others, by making a projection of the movement of people from Jakarta to Surabaya and vice versa, and 
projecting the number of people who switch to using express train transportation when the train is operated.

The results of the projected number of passengers will be used as material for the estimation of income. The results of the projected amount will be used as input in subsequent analyzes, especially the analysis of facility requirements with certain operating patterns. The results of the formulation of facility requirements and operating models will be used as material for analysis of estimated investment costs for facilities, operating costs, and repair, maintenance \& spare parts.

e. Investment criteria

The method adopted in calculating the economic \& financial feasibility is to evaluate the transportation project, the feasibility of economic and financial aspects. The project evaluation method is carried out to determine the level of feasibility by analyzing investment costs, operational costs, costs that may arise incurred by the community, benefits, and operating revenues related to transportation.

The standard evaluation criteria and indicators commonly used in economic viability include Net Present Value (NPV), Economic Internal Rate of Return (EIRR), Benefit-Cost Ratio (BCR), and added the Financial Rate of Return (FIRR) and Break-Even Point (BEP) for financial feasibility. In general, all of these indicators will provide a scale that compares the value of benefits/income and costs of each proposed alternative, but specifically, each indicator has different characteristics.

f. Economic and financial hypotheses on the determination of PPP

Hypothesis results on economic and financial aspects will give an indication of whether the operation of the Jakarta-Surabaya express train is feasible to operate or not economically and financially. If it is feasible to operate, its feasibility is based on the selection of 4 types of PPP according to the rules of Bappenas2) as shown in Table 3.

Table 3 PPP types according to Project Feasibility and Institutional Scheme

\begin{tabular}{|c|c|c|c|c|}
\hline & PROJECT FEASIBILITY & \multicolumn{2}{|c|}{ SCHEME } & PPP TYPE \\
\hline \multirow{2}{*}{1} & \multirow{2}{*}{$\begin{array}{l}\text { Feasible in Economy } \\
\text { and Financial)* }\end{array}$} & \multicolumn{2}{|c|}{ Private/N-L State Own. Comp. } & \multirow{2}{*}{ PPP REGULAR } \\
\hline & & \multicolumn{2}{|c|}{ Private/N-L State Own. Comp. } & \\
\hline \multirow{2}{*}{$2 a$} & \multirow{2}{*}{$\begin{array}{l}\text { Feasible in Economy } \\
\text { but Marginally in } \\
\text { Financial }\end{array}$} & \multicolumn{2}{|c|}{ Private/N-L State Own. Comp. } & \multirow{2}{*}{$\begin{array}{l}\text { PPP with Government } \\
\text { support in the form } \\
\text { of AP }\end{array}$} \\
\hline & & Government & $\begin{array}{c}\text { Private/N-L State } \\
\text { Own. Comp. }\end{array}$ & \\
\hline \multirow{2}{*}{$2 b$} & \multirow{2}{*}{$\begin{array}{l}\text { Feasible in Economy } \\
\text { but Marginally in } \\
\text { Financial }\end{array}$} & \multicolumn{2}{|c|}{ Private/N-L State Own. Comp. } & \multirow{2}{*}{$\begin{array}{l}\text { PPP with Government } \\
\text { support in the form of } \\
\text { VGF, funding for land } \\
\text { acquisition, funding for } \\
\text { part of the construction }\end{array}$} \\
\hline & & Government & $\begin{array}{l}\text { Private/N-L State } \\
\text { Own. Comp. }\end{array}$ & \\
\hline \multirow{2}{*}{3} & \multirow{2}{*}{$\begin{array}{l}\text { Feasibility in Economy } \\
\text { but Not Feasible in } \\
\text { Financial }\end{array}$} & \multicolumn{2}{|c|}{ Private/N-L State Own. Comp. } & \multirow{2}{*}{$\begin{array}{l}\text { Hybrid Financing/ } \\
\text { PPP Service } \\
\text { availability }\end{array}$} \\
\hline & & \multicolumn{2}{|c|}{ Government } & \\
\hline \multicolumn{2}{|c|}{-) It should be done by Private sector } & \multicolumn{2}{|c|}{ Operation and Maintenance } & \\
\hline & & \multicolumn{2}{|c|}{ Construction } & \\
\hline
\end{tabular}

Recommendations will be focused on the following matters.

1. If the results of the feasibility study produce indicators that are not feasible, then the feasibility study is recommended not to be done. 
2. If the feasibility study produces feasible indicators, then the study can be recommended to proceed with the feasibility study, which is supported by more complete, detailed, and accurate data.

This study focuses on determining the type of PPP validated through Value for Money (VfM) analysis for the feasibility indicator review. The results of financial analysis on four alternative scenarios in terms of IRR value compared to social discount factors (SDF) are as follow:

a. Financial analysis in scenario A is obtained IRR value: $37.69 \%>$ SDF, in which $10 \%$ selected OM Facility PPPs type plus 13\% TOD Fare Box. A high percentage of TOD ( $>$ $5 \%$ ) is considered challenging for private parties to undertake; thus, project fragmentation must be carried out so that the project cash flow meets the FIRR eligibility

b. Financial analysis in scenario B obtained IRR value that is $37.13 \%>$ SDF, in which $10 \%$ selected OM Facility PPPs type plus 13\% TOD Fare Box. A high percentage of TOD (> $5 \%$ ) is considered challenging for private parties to undertake; thus, project fragmentation must be carried out so that the project cash flow meets the FIRR eligibility

c. Financial analysis in scenario C obtained IRR value: $10.78 \%>$ SDF, in which $10 \%$ selected $49 \%$ VGF PPPs type + GS20\% + 7\% TOD Fare Box. TOD value of 5\% Fare Box is still prevalent in the calculation of TOD on regional lines meaning that this condition there is convenient for the private sector. (GS: Government Support for Construction)

d. In the financial analysis of scenario D obtained IRR value: $12.08 \%>$ SDF, in which $10 \%$ selected 49\% VGF PPPs type + GS20\% + 3\% TOD Fare Box. TOD3 value of Fare Box is very common in the calculation of TOD on regional lines so that with this condition, there are not many problems for the private sector.

\subsection{An Alternative Scenario Selection Hypothesis}

From the economic and financial feasibility data on the four alternative scenarios, it can be concluded that the best alternative scenario after combining the economic and financial analysis results with the technical aspect of the operating system, the considerations in selecting the best alternative scenario are as follows:

1. The priority order of excellence for PPP types in accordance with the 2016 PPP Toolkit Preparation Book is, the first priority is Regular PPP, second priority is Available of Payment (AP) PPPs or its fragmentation, the third priority is VGF PPPs or its fragmentation, and the last one is Service Availability PPPs / Hybrid Financing.

2. PPP type that is likely considered by the Government is the regular PPP type, in which the Government only provides the land for the project, while other project costs are prepared by the private sector.

3. PPP type that is of Government's considerable interest is the AP PPPs type or 49\% VGF PPPs type or 49\% VGF PPPs plus 20\% Government Support for Construction.

4. PPP type that can still be of interest to the government is the OM Facility PPPs type, which is the result of fragmentation from the VGF or AP that does not meet the eligibility to the private sector.

Based on these considerations, the prioritized alternative scenario resulted from the evaluation of the technical aspect are scenario D, followed by scenario C, B, and A. However, if political aspect, as in government's interference in the feasibility study, is considered, then the scenario $\mathrm{B}$ is prioritized. 


\subsection{Value for Money (VfM) Analysis}

\subsubsection{Model Validation: Numerical Trials}

The object for the analysis is the addition of new rail lines to the existing Jakarta-SemarangSurabaya Railway and interchange stations, including Manggarai, Tawang, and Pasar Turi. With details as described below:

a. Location: Jakarta-Surabaya railway track, 178 hectares of mixed building area near Manggarai Station, 88 hectares of mixed building area near Semarang Station, and 84 hectares of mixed building area near Pasar Turi Station.

b. Facilities:

- Public Service: Jakarta-Semarang-Surabaya rail passenger service

- Semi-Public: waiting room, outlets, health clinic, and mosque in the station area

- Commercial: retail services, parking, apartments, shopping centers, and hotels

c. PPP Type: Investment in the construction of the depot, provision of trainset, development of neighborhood areas such as parking, apartments/hotels, and shopping center is undertaken by the private sector through concession agreement as well as financing the facility operational costs for rolling stock and depots, while income is generated from facilities such as farebox, rental of properties in the neighborhood development area.

The result data of numerical trial and the value of the variable in actual condition can be seen in Table 4 and Table 5, respectively.

Table 4 Numerical Trial calculation result (IDR Billion)

\begin{tabular}{|c|c|c|c|}
\hline NO & ITEM & TOTAL & EXPLANATION \\
\hline 1 & $\begin{array}{l}\text { Project Investment (total } \\
\text { of Investment Capital) }\end{array}$ & 120,987 & $\begin{array}{l}\text { Investment Capital Cost of the } \\
\text { Project }\end{array}$ \\
\hline 2 & $\begin{array}{l}\text { Revenue (from economy } \\
\text { and financial aspect) }\end{array}$ & 112,264 & Farebox, Non-Farebox \\
\hline 3 & Operational Cost & 16,470 & $\begin{array}{l}\text { General and administration cost, } \\
\text { marketing cost, facility and } \\
\text { infrastructure cost, HRD cost }\end{array}$ \\
\hline 4 & Income Tax & 528 & Tax of individual's revenue \\
\hline 5 & Administration Cost & 2,456 & $\begin{array}{l}\text { Administration cost for } \\
\text { construction (license) }\end{array}$ \\
\hline 6 & Risk Cost & 1,936 & Cost if any operation risk \\
\hline \multirow[b]{2}{*}{ PPP } & \multicolumn{2}{|c|}{$\begin{array}{l}\text { NFBs1 (Outputs): Non-financial benefit } \\
\text { on PSC (Pure Gov Project) }\end{array}$} & $\begin{array}{l}\text { NFBs2 (Gross Value Added): } \\
\text { Non-financial benefit on PPP }\end{array}$ \\
\hline & \multicolumn{2}{|r|}{56,247} & 7,110 \\
\hline $\begin{array}{l}\text { NON- } \\
\text { PPP }\end{array}$ & \multicolumn{2}{|r|}{49,137} & 1,777 \\
\hline $\begin{array}{l}\text { Descr } \\
\text { iption }\end{array}$ & \multicolumn{2}{|c|}{$\begin{array}{l}\text { Non Financial benefit if the railway } \\
\text { services always used by the public. }\end{array}$} & $\begin{array}{l}\text { Non-Financial Benefit from } \\
\text { increasing the business value of } \\
\text { TOD and around the Station }\end{array}$ \\
\hline
\end{tabular}

Source: Analysis result

Note : NFBs1 = Non Financial benefit on PSC

NFBS2 = Non Financial benefit on PPP 
Table 5 Value for Variables in Actual Condition (IDR Billion)

\begin{tabular}{|c|c|c|c|c|c|}
\hline \multicolumn{3}{|c|}{ PSC (RAW PSC) } & \multicolumn{3}{|c|}{ PPP (SERVICE PAYMENT) } \\
\hline $\mathrm{R} 1$ & Operational Cost of PSC & 22,658 & S1 & $\begin{array}{l}\text { Operational costs incurred by } \\
\text { the government after deducting } \\
\text { operational costs borne by the } \\
\text { private sector }\end{array}$ & 5,912 \\
\hline $\mathrm{R} 2$ & $\begin{array}{l}\text { Overall project revenue } \\
\text { (Economic and Financial) }\end{array}$ & 49,137 & S2 & $\begin{array}{l}\text { Government revenue from } \\
\text { Revitalization after sharing with } \\
\text { private parties }\end{array}$ & 16,874 \\
\hline R3 & Overall project investment capital & 120,987 & S3 & $\begin{array}{l}\text { Investment capital from the } \\
\text { government after de-ducting } \\
\text { private investment }\end{array}$ & 111,588 \\
\hline Total & & 94,509 & Total & & 100,627 \\
\hline \multicolumn{3}{|c|}{ COMPETITIVE NEUTRALLY } & $\begin{array}{l}\text { Retaine } \\
\text { d Risk }\end{array}$ & $\begin{array}{ll}\text { Risks of land preparation for } \\
\text { revitalization, land use } \\
\text { planning, neighborhood area } \\
\text { strengthening, } & \text { line } \\
\text { strengthening \& access } & \\
\end{array}$ & 513 \\
\hline $\mathrm{C} 1$ & $\begin{array}{l}\text { Costs for establishing } \\
\text { management, cooperation costs } \\
\text { with the private sector in the } \\
\text { project promotion costs }\end{array}$ & 469 & & \multicolumn{2}{|l|}{ NFBs } \\
\hline $\begin{array}{c}\mathrm{C} 2 \\
(\mathrm{PPH})\end{array}$ & $\begin{array}{l}\text { Income Tax from Railway Line } \\
\text { Revitalization }\end{array}$ & 2,528 & NFBs1 & $\begin{array}{l}\text { Benefits of trains for mass } \\
\text { passenger transport. are better } \\
\text { known and are often used, than } \\
\text { money spent by the train service } \\
\text { user \& savings from other } \\
\text { sectors }\end{array}$ & 259,816 \\
\hline $\begin{array}{c}\mathrm{C} 3 \\
(\mathrm{PBB})\end{array}$ & $\begin{array}{l}\text { Land and Building Tax on } \\
\text { Railway Revitalization Program }\end{array}$ & 0 & NFBs2 & $\begin{array}{l}\text { Increased business value in the } \\
\text { Revitalization and TOD area }\end{array}$ & 42,662 \\
\hline Total & & 2,998 & Total & & 302,478 \\
\hline $\begin{array}{l}\text { Retaine } \\
\text { d Risk }\end{array}$ & $\begin{array}{l}\text { Risks of land preparation for } \\
\text { revitalization, land arrangement } \\
\text { or the station \& neighborhood } \\
\text { area, land and access preparation }\end{array}$ & 6 & TOTAL & & 201,337 \\
\hline $\begin{array}{l}\text { Transfer } \\
\text { red Risk }\end{array}$ & $\begin{array}{l}\text { Risks of railway line } \\
\text { revitalization }\end{array}$ & 265 & & & \\
\hline \multicolumn{3}{|c|}{ NFBs = Non-Financial Benefit (PSC) } & & & \\
\hline NFBs1 & $\begin{array}{l}\text { The benefits of having a train for } \\
\text { mass transport are better known } \\
\text { and often used than savings in } \\
\text { economic value incurred by the } \\
\text { community of rail users as well as } \\
\text { savings in OM costs from other } \\
\text { affected sectors }\end{array}$ & 51,919 & & & \\
\hline NFBs2 & $\begin{array}{l}\text { Increased business value in the } \\
\text { project area, Gross Value Added } \\
\text { (rental property, TOD, etc.) }\end{array}$ & 4,724 & & & \\
\hline $\begin{array}{c}\text { Total } \\
\text { NFBS }\end{array}$ & & 56,644 & NPV & & 27,982 \\
\hline Total & & 41,135 & & & \\
\hline NPV & & 97,779 & & & \\
\hline
\end{tabular}


Based on the data provided above, it can be seen that the VfM has a positive value indicating that the Jakarta-Surabaya Railway Project is better held with an Operation \& Maintenance PPP scheme and the cost savings obtained by the Government amounted to 21,450,729.6 (IDR Million) with an estimated Government profit of $25 \%$ of total revenues for the long term (50 years).

Table 6 Calculation of VfM Value of Actual Condition (IDR Billion)

\begin{tabular}{|c|r|c|r|}
\hline \multicolumn{2}{|c|}{ PSC (i: 8\%) } & \multicolumn{2}{c|}{ OM PPPs } \\
\hline R & 94,509 & S & 100,627 \\
\hline CN & 2,998 & RR2 & 513 \\
\hline RR1 & 6 & NFBs & 302,478 \\
\hline TR & 265 & & \\
\hline NFBs & 56,644 & & $(201,337)$ \\
\hline Total & 41,135 & Total & $(186,423)$ \\
\hline NPV & 38,088 & NPV & $\mathbf{2 2 4 , 5 1 1}$ \\
\hline & & & \\
\hline
\end{tabular}

\subsubsection{Model Validation: Sensitivity Analysis}

Several observations obtained from the result of sensitivity analysis are as follow:

- The variables are concession period that affects other variables, not only the final result (VfM value) but also operating costs and revenues.

- The longer the concession period, the higher the VfM value.

- For the 10-year concession period, in the sense that it is 40 years earlier than the project life, therefore, the VfM value increases $13 \%$ from the actual condition.

- For the 20-year concession period, in the sense that it is 30 years earlier than the project life, therefore, the VfM value increases $4 \%$ from the actual condition,

- It is caused by the income from the private sector is greater than the borne operational costs of the facilities and depos.

Table 7 Effects of Changes in the Concession Period (IDR Billion)

\begin{tabular}{|c|c|c|c|c|c|c|c|c|c|}
\hline \multicolumn{2}{|c|}{$\mathrm{i}: 8 \%$} & \multicolumn{2}{|c|}{ Actual (50 years) } & \multicolumn{2}{|c|}{10 years } & \multicolumn{2}{|c|}{20 years } & \multicolumn{2}{|c|}{15 years } \\
\hline \multicolumn{2}{|c|}{ PSC } & \multicolumn{2}{|c|}{ PSC } & \multicolumn{2}{|c|}{ OM PPPs } & \multicolumn{2}{|c|}{ OM PPPs } & \multicolumn{2}{|c|}{ OM PPPs } \\
\hline $\mathrm{R}$ & 94,509 & $\mathrm{~S}$ & 100,627 & $\mathrm{~S}$ & 104,278 & $\mathrm{~S}$ & 99,178 & $\mathrm{~S}$ & 101,430 \\
\hline $\mathrm{CN}$ & 2,998 & RR2 & 513 & RR2 & 513 & RR2 & 513 & RR2 & 513 \\
\hline RR1 & 6.38 & NFBs & 302,478 & NFBs & 275,428 & NFBs & $\begin{array}{r}290,13 \\
6\end{array}$ & NFBs & 283,762 \\
\hline $\mathrm{TR}$ & 265 & & & & & & & & \\
\hline NFBs & 56,644 & & & & & & & & \\
\hline Total & 41,135 & Total & $(201,337)$ & Total & $(170,637)$ & & $\begin{array}{r}(190,4 \\
44)\end{array}$ & Total & $(181,818)$ \\
\hline NPV & 38,088 & NPV & $(186,423)$ & NPV & $(157,997)$ & & $\begin{array}{r}(176,3 \\
37)\end{array}$ & NPV & $(168,350)$ \\
\hline \multicolumn{2}{|c|}{$V f M$} & \multicolumn{2}{|c|}{224,511} & \multicolumn{2}{|c|}{196,085} & \multicolumn{2}{|c|}{214,425} & \multicolumn{2}{|c|}{206,438} \\
\hline \multicolumn{2}{|c|}{ Percentage of VfM } & & & \multicolumn{2}{|c|}{$13 \%$} & \multicolumn{2}{|c|}{$4 \%$} & \multicolumn{2}{|c|}{$8 \%$} \\
\hline
\end{tabular}


Table 8 Effect of Investment Proportion (IDR Billion)

\begin{tabular}{|c|c|c|c|c|c|c|c|c|}
\hline \multicolumn{2}{|c|}{ i:8\% } & \multicolumn{2}{|c|}{$\begin{array}{c}\text { Actual } \\
(\mathbf{8 7 . 8 0 / 1 2 . 2 0})\end{array}$} & $49 / 51$ & 30/70 & 70/30 & $\begin{array}{c}100 \% \\
\text { Gov }\end{array}$ & $100 \%$ Pte \\
\hline \multicolumn{2}{|c|}{ PSC } & \multicolumn{2}{|c|}{ PPP (OM PPPs) } & $\begin{array}{c}\text { PPP } \\
\text { (VGF1) }\end{array}$ & $\begin{array}{c}\text { PPP } \\
\text { (VGF2) }\end{array}$ & $\begin{array}{c}\text { PPP } \\
\text { ( VGF3) }\end{array}$ & PPP & PPP \\
\hline $\mathrm{R}$ & 94,509 & $\mathrm{~S}$ & 100,627 & 64,302 & 49,470 & 80,694 & 104,113 & 26,052 \\
\hline $\mathrm{CN}$ & 2,998 & $\mathrm{RR} 2$ & 513 & 513 & 513 & 513 & 513 & 513 \\
\hline RR1 & 6.38 & NFBs & 302,478 & 302,478 & 302,478 & 302,478 & 302,478 & 302,478 \\
\hline TR & 265 & & & & & & & \\
\hline NFBs & 56,644 & & & & & & & \\
\hline Total & 41,135 & Total & $(201,337)$ & $(237,663)$ & $(252,494)$ & $(221,270)$ & $(197,852)$ & $(275,913)$ \\
\hline NPV & 38,088 & NPV & $(186,423)$ & $(220,058)$ & $(233,792)$ & $(204,879)$ & $(183,196)$ & $(255,475)$ \\
\hline \multicolumn{2}{|c|}{ VfM } & \multicolumn{2}{|c|}{224,512} & 258,147 & 271,879 & 242,968 & 221,284 & 293,564 \\
\hline \multicolumn{2}{|c|}{$\begin{array}{c}\text { Percentage of } \\
\text { VfM }\end{array}$} & & & $15 \%$ & $21 \%$ & $8 \%$ & $-1 \%$ & $31 \%$ \\
\hline
\end{tabular}

Based on the data provided in Table 8 above, the participation of private investment is the initial purpose of the PPP scheme; therefore, it is necessary to know the influence of the government and private investment in the project investment. Moreover, the expenditure of investment funds for the government is also considered. In addition, the proportion of investment has an effect on the value of Service Payment, which affects the value of the investment borne by the government. It can be seen that the higher the proportion of government investment, the lower the VfM value.

Table 9 Effect of Discount Factor (IDR Trillion)

\begin{tabular}{|c|c|c|c|c|c|c|c|c|c|c|c|}
\hline \multicolumn{4}{|c|}{ Actual (i:8\%) } & \multicolumn{6}{|c|}{$4 \%$} & \multicolumn{2}{|c|}{$114 \%$} \\
\hline \multicolumn{2}{|c|}{ PSC } & \multicolumn{2}{|c|}{ PPP } & \multicolumn{2}{|c|}{ PSC } & \multicolumn{2}{|c|}{ PPP } & \multicolumn{2}{|c|}{ PSC } & \multicolumn{2}{|c|}{ PPP } \\
\hline $\mathrm{R}$ & 94.5 & $\mathrm{~S}$ & 100.6 & $\mathrm{R}$ & 93.6 & $\mathrm{~S}$ & 94.7 & $\mathrm{R}$ & 118.1 & $\mathrm{~S}$ & 94.7 \\
\hline $\mathrm{CN}$ & 2.9 & RR2 & 0.5 & $\mathrm{CN}$ & 2.9 & RR2 & 0.5 & $\mathrm{CN}$ & 2.9 & RR2 & 513.3 \\
\hline RR1 & 0.006 & NFBs & 302.5 & RR1 & 0.006 & NFBs & 302.5 & RR1 & 0.006 & NFBs & 302.5 \\
\hline TR & 0.3 & & 0,0 & TR & 0.3 & & 0,0 & TR & 0.3 & & 0,0 \\
\hline NFBs & 56.6 & & 0,0 & NFBs & 56.6 & & 0,0 & NFBs & 56.6 & & 0,0 \\
\hline Total & 41.1 & Total & $\begin{array}{r}(201 . \\
3)\end{array}$ & Total & 40.2 & Total & $\begin{array}{r}(207 . \\
3)\end{array}$ & Total & 64.7 & Total & (207.3) \\
\hline NPV & 38.1 & NPV & $\begin{array}{r}(186 . \\
4) \\
\end{array}$ & NPV & 38.6 & NPV & $\begin{array}{r}(199 . \\
3\end{array}$ & NPV & 30.3 & NPV & $(96.8)$ \\
\hline \multicolumn{2}{|c|}{ VfM } & \multicolumn{2}{|c|}{224.5} & \multicolumn{2}{|c|}{ VfM } & \multicolumn{2}{|c|}{237.9} & \multicolumn{2}{|c|}{ VfM } & \multicolumn{2}{|c|}{127.1} \\
\hline \multicolumn{2}{|c|}{$\begin{array}{c}\text { Percentage of } \\
\text { VfM } \\
\text { comparison }\end{array}$} & & & \multicolumn{4}{|c|}{$6.00 \%$} & \multicolumn{4}{|c|}{$-43.39 \%$} \\
\hline
\end{tabular}

Discount Factor (DF) is used to determine the present value of future cash flows, which can then be used to calculate future uncertainty. The size of the DF value will affect the return on investment capital. It can be seen from the data in Table 9 above that the changes in DF value affect the NPV calculation of the Total PSC and Total PPP. The smaller the DF, the higher the VfM value, and the smaller the DF value, the greater the NPV value because what is used as a reference is the cost, the greater NPV value for PPP is the NPV with the most negative value 
which means the savings or VfM value obtained by the government will be higher. The calculation above illustrates the relationship between NPV and DF is inversely proportional, i.e., the calculation results if the DF value is $4 \%$, then the VfM value increases by $6 \%$, whereas if the DF value is $114 \%$ then the VfM value decreases by $43.39 \%$.

\subsubsection{Validation Result: Graphic Analysis Model}

Validation by sensitivity analysis is done with the assumption that the sensitivity of the model is similar to the sensitivity of the actual system (Hana \& Negoro, 2010).

a. Concession Period

The model with longer the concession period parameter has its VfM value increases (see Figure 3). Changes in the concession period have an impact on the government's revenue, which is declining due to the sharing with the private sector, resulting in costs incurred increase.

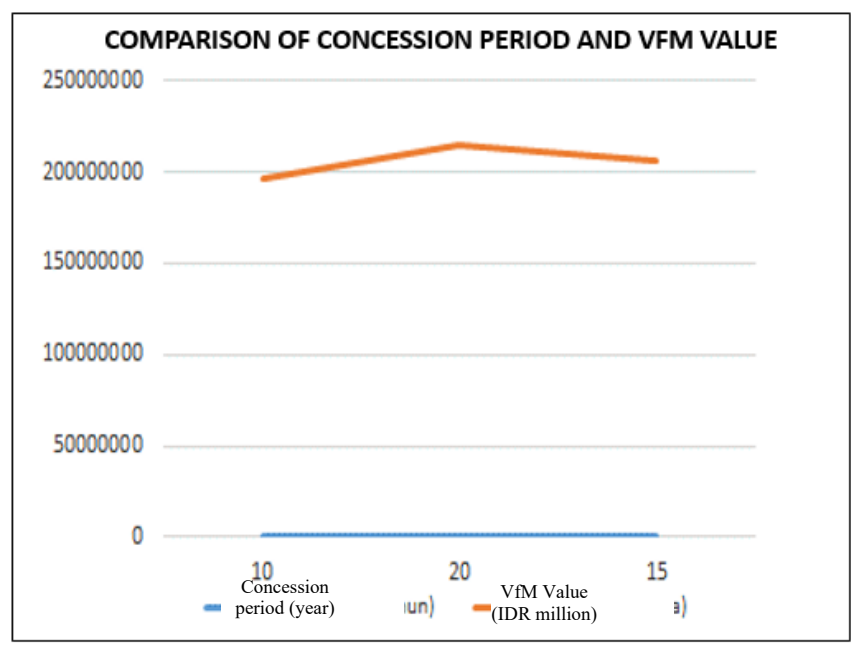

Figure 3 Comparison of Concession Period and VfM Value

b. Investment Proportion

The model with the greater the Government Investment parameter has its VfM value decreases (see Figure 4). A significant VfM value can be obtained if the investment proportion of Private is $100 \%$, with an increase in VFM of $31 \%$ with a VfM value of Rp. 293.56 trillion, but this is not feasible because the NPV value is negative (the value of the IRR was not reached). 


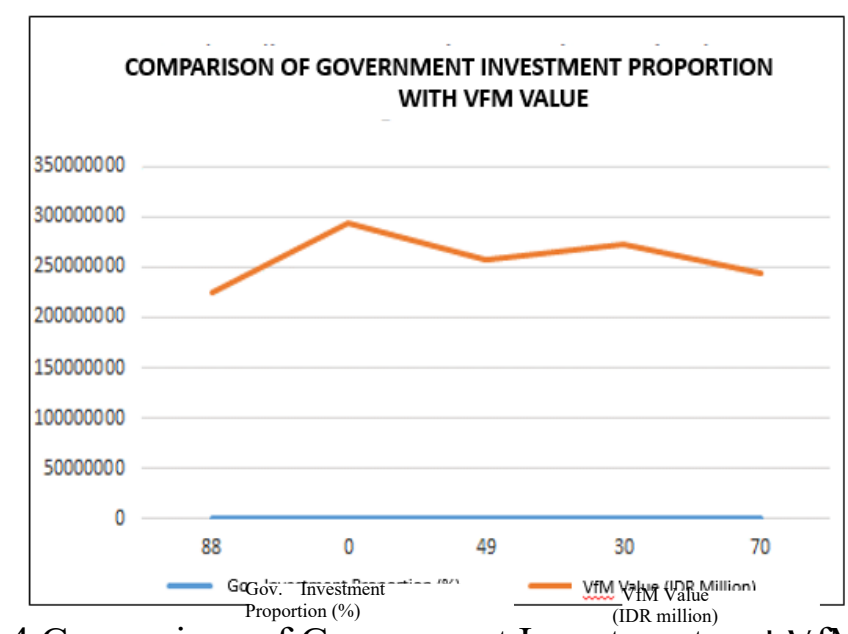

Figure 4 Comparison of Government Investment and VfM Value

\section{c. Discount Factors (DF)}

The model with the smaller the value of the DF parameter has the greater the value of NPV savings and the greater the value of VfM (see Figure 5). DF is a divisor in the NPV formula, so it has an inverse relationship. With reference to cost assessment, the smaller the DF, the smaller the NPV value, indicating increased savings. If the DF value of $114 \%$ is used, the impairment of VfM is $43 \%$; and if the DF value of $4 \%$ is used, the VfM value increases by $6 \%$.

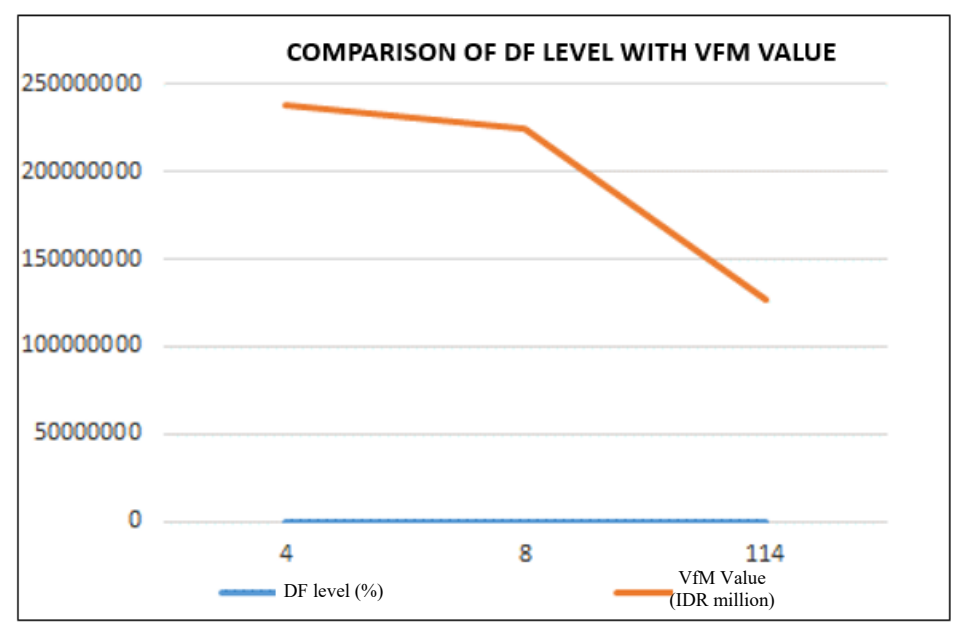

Figure 5 Comparison between DF value and VfM Value

\section{CONCLUSION}

Risky alternative scenario selection can occur if a decision considers more political aspects than technical and economic-financial aspects. Based on the technical ranking, the prioritized scenario is scenario D, followed by scenario C and B. However, due to political interference, then the scenario B needs to be validated by the PPP feasibility study through the VfM analysis.

The most significant change in the results of the analysis is impairment in VfM of scenario B if the proportion of investment by the government is $87.80 \%$ (OM PPPs) with discount factor (DF) rate of $114 \%$, the impairment in VfM is $43 \%$; and if DF rate used is $4 \%$, then the VfM value increases by $6 \%$.

Based on numerical trial results on project data, the VfM value of the actual data is 224.51 (IDR Trillion). The most significant change in VfM value for each variable change is in the 20 -year 
concession period which reduces the VfM value by 4\%; if the proportion of capital investment from the private sector is $100 \%$, this can increase the VfM value by $31 \%$; however, this is not feasible for the private sector because FIRR was not reached.

On the other hand, with the use of the DF rate of $114 \%$, it will reduce the VfM value by $43 \%$. Of all the variable changes, there is no minus VfM value, indicating that the public project is in good shape to be held with a PPP scheme in accordance with the feasibility of the FIRR, namely the OM Facility scheme as fragmentation of the VGF PPPs, with the optimum concession period is 20 years where the initial BEP Investment data is nine years old.

For future study, the Indonesian Ministry of Transportation is recommended to conduct a more detailed study on the speed improvement of the Jakarta-Surabaya railway project in order to meet the criteria of the most appropriate and most profitable PPP scheme to reduce the government budget requirements in the development of railway projects, including research on the application of the TOD system, propulsion technology, and rail track technology.

\section{ACKNOWLEDGMENT}

The authors would like to thank the Ministry of Transportation for funding this research.

\section{REFERENCES}

Bappenas. (2016). Web-Based PPP Toolkit Preparation. Bappenas. https://docplayer.info/72380324-Daftar-isi-latar-belakang-tujuan-toolkit-kpbupenerima-manfaat-2.html

BPS-Statistics of DKI Jakarta Province, 2018. (2020). DKI Jakarta Province in Figures 2020. https://jakarta.bps.go.id/dynamictable/2019/09/16/58/jumlah-penduduk-provinsi-dkijakarta-menurut-kelompok-umur-dan-jenis-kelamin-2018-.html

BPS-Statistics of Surabaya Municipality. (2020). Surabaya Municipality in Figures 2020. Statistics of Surabaya Municipality.

Chen, Z., Xue, J., Rose, A. Z., \& Haynes, K. E. (2016). The impact of highspeed rail investment on economic and environmental change in China: A dynamic CGE analysis. Transportation Research Part A: Policy and Practice, 92, 232-245.

Directorate of System and Infrastructure Transportation. (2017). Pra Feasibility Study Increased Speed Railway of Jakarta-Surabaya, Agency for the Assessment and Application of Technology Republic of Indonesia.

Evans, A. W. (2013). The economics of railway safety. Research in Transportation Economics, $43,137-147$.

Grimsey, D., \& Lewis, M. K. (2002). Evaluating the risks of public private partnerships for infrastructure projects. International Journal of Project Management, 20(2), 107-118. https://doi.org/10.1016/S0263-7863(00)00040-5

Hana, \& Negoro, N. P. (2010). Evaluasi Value for Money (VfM) pada Proyek Publik di Surabaya. http://digilib.its.ac.id/public/ITS-paper-33528-2510100007-Paper.pdf

Hui, S., Ying, Z., \& Zhi-qing, F. (2010). Value for money test in infrastructure procurement. 2010 International Conference on Logistics Systems and Intelligent Management (ICLSIM). https://doi.org/10.1109/ICLSIM.2010.5461363

Ismail, K., Takim, R., \& Nawawi, A. H. (2012). A Public Sector Comparator (PSC) for Value for Money (VFM) Assessment Tools. Asian Social Science, 8(7). https://doi.org/doi:10.5539/ass.v8n7p192

Morallos, D., \& Amekudzi, A. (2008). The State of the Practice of Value for Money Analysis in Comparing Public Private Partnerships to Traditional Procurements: Public Works Management \& Policy. https://doi.org/10.1177/1087724X08326176 
Morallos, D., Amekudzi, A., Ross, C., \& Meyer, M. (2009). Value for Money Analysis in U.S. Transportation Public-Private Partnerships. Transportation Research Record, 2115(1), 27-36. https://doi.org/10.3141/2115-04

Ng, S. T., Wong, Y. M. W., \& Wong, J. M. W. (2012). Factors influencing the success of PPP at feasibility stage - A tripartite comparison study in Hong Kong. Habitat International, 36(4), 423-432. https://doi.org/10.1016/j.habitatint.2012.02.002

Nisar, T. M. (2007). Value for money drivers in public private partnership schemes. https://doi.org/10.1108/09513550710731508

Nurhidayat, A. Y., Widyastuti, H., \& Utomo, D. P. (2018). Model of transportation mode choice between aircraft and high speed train of Jakarta-Surabaya route. 202, 012002. https://doi.org/doi:10.1088/1755-1315/202/1/012002

Park, H., Lee, S., \& Kim, J. (2018). Do public private partnership projects deliver value for money? An ex post Value for Money (VfM) Test on three road projects in Korea: International Journal of Urban Sciences: Vol 22, No 4. International Journal of Urban Sciences, 22(4), 579-591. https://doi.org/ttps://doi.org/10.1080/12265934.2018.1455528

Utomo, D. P., Lestari, D. R., Sucipto, \& Nurhidayat, A. Y. (2020). Impact of the JakartaSurabaya High-Speed Train on Passengers of the Jakarta-Surabaya Executive Train Corridor. Journal of Industrial Technology Assesments, 14(1). https://doi.org/10.29122/mipi.v14i1.3897.g3413

Vives, A., Benavides, J., \& Paris, A. M. (2010). Selecting Infrastructure Delivery Modalities: No Time for Ideology or Semantics. Journal of Construction Engineering and Management, 136(4), 412-418. https://doi.org/10.1061/(ASCE)CO.1943-7862.0000113

Zhang, X. (2005). Paving the Way for Public-Private Partnerships in Infrastructure Development | Journal of Construction Engineering and Management | Vol 131, No 1. Journal of Construction Engineering and Management, 131(1), 71-80. 